\title{
Failure Mode and Effect Analysis (FMEA) for confectionery manufacturing in developing countries: Turkish delight production as a case study
}

\author{
Análise dos Efeitos e Modos de Falhas (FMEA) para fabricação de doces em países em desenvolvimento: \\ produção de Delícia turca como um estudo de caso
}

\author{
Sibel OZILGEN ${ }^{1 \star}$
}

\begin{abstract}
The Failure Mode and Effect Analysis (FMEA) was applied for risk assessment of confectionary manufacturing, in whichthe traditional methods and equipment were intensively used in the production. Potential failure modes and effects as well as their possible causes were identified in the process flow. Processing stages that involve intensive handling of food by workers had the highest risk priority numbers $(\mathrm{RPN}=216$ and 189), followed by chemical contamination risks in different stages of the process. The application of corrective actions substantially reduced the RPN (risk priority number) values. Therefore, the implementation of FMEA (The Failure Mode and Effect Analysis) model in confectionary manufacturing improved the safety and quality of the final products.

Keywords: FMEA; traditional food; confectionery; food safety; Turkish delight.
\end{abstract}

\section{Resumo}

Análise dos Efeitos e Modos de Falhas (FMEA) foi aplicada para avaliação de risco de fabricação de produtos de confeitaria, na qual os métodos tradicionais e equipamentos foram intensamente utilizados na produção. Efeitos e modos de falhas potenciais e suas possíveis causas foram identificados no fluxo do processo. Os estágios de processamento que involve grande manipulação de alimentos pelos trabalhadores obteve os maiores números de prioridade de risco ( $\mathrm{NRP}=216$ e 189), seguido por riscos de contaminação química em diferentes fases do processo. A aplicação das medidas corretivas reduziu substancialmente os NRP (números de prioridade de risco). Portanto, a implementação do modelo de FMEA (Análise dos Efeitos e Modos de Falhas) na fabricação de confeitos melhorou a segurança e qualidade dos produtos finais. Palavras-chave: FMEA; comida tradicional; confeitaria; segurança alimentar; Delícia turca.

\section{Introduction}

Traditional foods and confectioneries still constitute a major part of the culinary culture especially in developing countries. In general, preparation of these foods is simple, and their ingredients are common almost in every part of the world. Traditional foods are produced over the years both at home and in small or large scale companies. There is an intensive handling by workers, many steps are carried out manually, and usually traditional equipment is used during the production of these foods and hygiene rules and regulations are mostly overlooked in the premises. (WORLD..., 2008).

Turkey is one of the fastest developing countries in the world. The Turkish confectionery industry is one of the country's leading food industries, and the yearly production volume of Turkish delight makes almost $10 \%$ of total confectionary production in Turkey(DOYURAN; GÜLTEKIN; GÜVEN, 2006). In 2001, the total confectionary production was 429 thousand tons, from which about 42 thousand tons was Turkish delight (DOYURAN; GÜLTEKIN; GÜVEN, 2006). Turkey is among the primary 15 countries which are the largest exporter of sugar confectionery, chocolate, biscuits, and cocoa products in the world, and Turkish delight accounts for nearly
$1.7 \%$ of confectionary exported to different parts of the world. Germany, USA, Holland, France, England, and Belgium are the main Turkish delight importers (PALACIOĞLU, 2009).

Effective risk control by selecting and implementing appropriate measures is very important to protect public health and build consumer trust (KLEEF et al., 2009). Safety issues associated with some commercially available Turkish delight samples have been notified due to lack of systematic tracking of their production (DILVIN; ZORBA, 2008; SIRIKEN; ÇADIRCI, 2006; BATU; KIRMACI, 2009). Failure Modes and Effect Analysis (FMEA) is the commonly used tool for quality assurance in many manufacturing industries addressing customer and governmental requirements, quality control, and safety (TENG; HO, 1984; SEGISMUNDO; MIGUEL, 2008). It is a systematic preventive method used to define, identify, and eliminate the potential product failures from the process. Potential risks of a process are assessed by defining the value for frequency of a failure $(\mathrm{O})$, severity of the failure $(\mathrm{S})$, and ability to detect the failure (D) before consumption. The values of three variables are multiplied $(\mathrm{O} \times \mathrm{S} \times \mathrm{D})$ to calculate the Risk Priority Number (RPN) for each failure. Corrective actions are suggested

${ }^{1}$ Department of Food Engineering, Yeditepe University, Kayisdagi-34755, Istanbul, Turkey, e-mail: sozilgen@yeditepe.edu.tr

${ }^{*}$ Corresponding author 
based on the results of risk assessment to reduce or eliminate the potential failures from the system (SCIPIONI et al., 2002; ARVANITOYANNIS; VARZAKAS 2007a, b, 2008; SZOVATI; BIACS; KISS, 2008; OZILGEN et al., 2011).

This study applies the FMEA methodology for the risk assessment in a small scale confectionery manufacturing company, in which traditional methods and equipment are intensively involved in the processing stages. Turkish delight production was chosen as a case study since: 1 ) it is the most famous traditional Turkish confectionary which is produced both in large-scale plants and in small-scale companies; 2) its production involves the most common ingredients and the processing stages in many other confectioneries; and 3) safety of the final product can affect the health of a large number of people since the yearly production and the export volume are very high.

\section{Materials and methods}

The flow diagram for "Turkish delight with nut fillings" production is given in Figure 1. Sugar, water, and corn starch are mixed and cooked in an open vessel at maximum $125^{\circ} \mathrm{C}$ for 2 to 2.5 hours. Citric acid is added during cooking to prevent sugar crystallization. The hot mixture is poured into a tray or a mold, which is dusted with powdered sugar to prevent Turkish delight from sticking to the mold. Turkish delight is cut into small pieces after cooling, dusted with powdered sugar, packed, stored, and sold. Nuts and dried fruits are added during or after the process depending on the type of Turkish delight produced (BATU; KIRMACI, 2009).

Potential failure modes, Critical Points (CP), were incorporated in the process flow diagram, which involves traditional methods and utensils in the production. For the purpose of this study, Critical Points were defined as " $[. .$.$] the$ stages at which the potential failure risk is high due to intensive human handling, the equipment used in the process, and the environmental conditions." Potential failures and their possible causes were identified for each failure mode (Table 1). The risk level of potential failures was identified by calculating a risk priority number (RPN) from three variables: occurrence $(\mathrm{O})$, severity (S), and detection possibility (D) of failures. A numerical ranking for the variables $\mathrm{O}, \mathrm{S}$, and $\mathrm{D}$ of failures was established. Each failure mode was identified whether or not the failure is likely to occur on a scale of 1 to 10 . The highest ranking indicates the greatest probability of failures. The possibility for detecting the failures (D) prior to consumption and their severity $(\mathrm{S})$ were also rated on a scale from 1 to 10 , where 10 indicates the least likely chance of detecting the failure prior to occurring and very severe effect of the failure on human health, respectively. The risk priority numbers were calculated by multiplying the values of the variables $\mathrm{O}, \mathrm{S}$, and D. The RPNs were obtained using Matlab statistical software, (The MathWorks, Inc.). The risk priority numbers higher than 100 were considered as the potential failures, and therefore those that required improvement actions. The maximum value of a possible RPN is $1000(10 \times 10 \times 10)$, and 100 is $10 \%$ of this amount with a statistical confidence of $90 \%$. Possible control measures were suggested for each potential failure mode, and
RPNs were calculated in order to understand the influence of corrective actions in process improvement (Table 1). The analysis was based on information obtained from highly experienced food safety auditors in Turkey (practical information) and studieson similar food items in the literature. Pareto diagrams (Figure $2 \mathrm{a}, \mathrm{b}$ ) were constructed by following the procedure proposed by Arvanitoyannis and Savelides (2007) to visualize the percent contribution of the RPN of each processing stage to the total RPN of the process before and after implementing the corrective actions.

\section{Results and discussion}

Cross-contamination due to poor personal hygiene and unsanitary practices was the major potential risk in the process especially in the cooking, pouring, molding, and cutting stages $(\mathrm{RPN}=216$ and 189) (Table 1). Staff education regarding proper food handling practices, personal hygiene, and food safety rules are important to minimize the problems arising from workers in different stages of the process (OZILGEN, 2011; MALHOTRA et al., 2007). Adequate changing rooms and bathrooms and hand washing facilities with hot and cold water, soap, and paper towel should be available for staff to ensure that a proper degree of personal hygiene can be maintained (WORLD..., 2008). Appropriate cleaning, disinfection and rinsing of vessels, cutting boards, and utensils after each use will minimize the risk of cross-contamination and the occurrence of pathogens (Table 1).

Copper leaching into Turkish delight was identified as a potential risk in the cooking, pouring, and molding stages since small scale confectionery companies usually prefer to use traditional equipment like copper utensils and vessels in their processes $(\mathrm{RPN}=192)$. Both copper deficiency and excess can cause adverse health effects. Accidental ingestion is considered one of the main reasons for acute copper toxicity (STERN et al., 2007). Equipment and utensils coming into contact with foods should be manufactured from non-toxic materials. Replacing copper equipment with stainless steel equipment will minimize the problem in this process. Although the RPN value was relatively low, heavy metal contamination was determined as a potential risk even in water $(\mathrm{RPN}=126)$. Iron is the most widely used metal in pipelines and fittings. Corrosion is one of the main problems associated with iron and needs to be avoided. Lead, copper, and zinc are the other possible metal contaminants of water depending on the pipe-line construction of the buildings. Inspection and investigation of pipe work in buildings, and the $\mathrm{pH}$ of water are important factors to be controlled and managed to minimize the risk of metal contamination in water. The presence of chlorine residual in water above the legal limits have similar potential risk if certain requirements are not satisfied $(\mathrm{RPN}=126)$. Chlorine is used as a common disinfectant in water. Increased chlorine concentration in water primarily decreases the sensorial quality of water and the quality of the products if water is used in their processes. Although no adverse toxicological effects of increased chlorine concentration were observed in studies conducted with males, dermatitis, bladder cancer, increased serum cholesterol and low lipoprotein were 
associated with exposure to chlorine and hypochlorite in other studies (WORLD..., 2003).

The level of chlorine needs to be continuously monitored by the authorities. Large number of local populations obtain their drinking water from private water supplies or from their own wells, which may increase the risks of chemical and biological contamination $(\mathrm{RPN}=189)$ in water. Using potable water treated and monitored by local authorities could be the best solution addressing the potential risks in water.

The existence of other contaminants such as pesticides, insecticides, and aflatoxinsin food are considered as a high potential risk in different stages of the process (RPN ranged between 189 and 140). The level of pesticides in foods and drinking water is important since prolonged exposure can result in soft tissue, brain, lung, liver, digestive system, and urinary tract cancers, birth defects, and damage to the nervous systems (YOUNES; GALAL-GORCHEV, 2000; NEW JERSEY, 2002). Fungal spoilage and aflatoxin contamination in many foods such as nuts, corn, dried figs, and sugar are of major concern since they are extremely toxic and, carcinogenic causing mutagenic effects on human health. The producer should specify the safety and quality requirements of incoming ingredients based on the food codex. Raw ingredients should

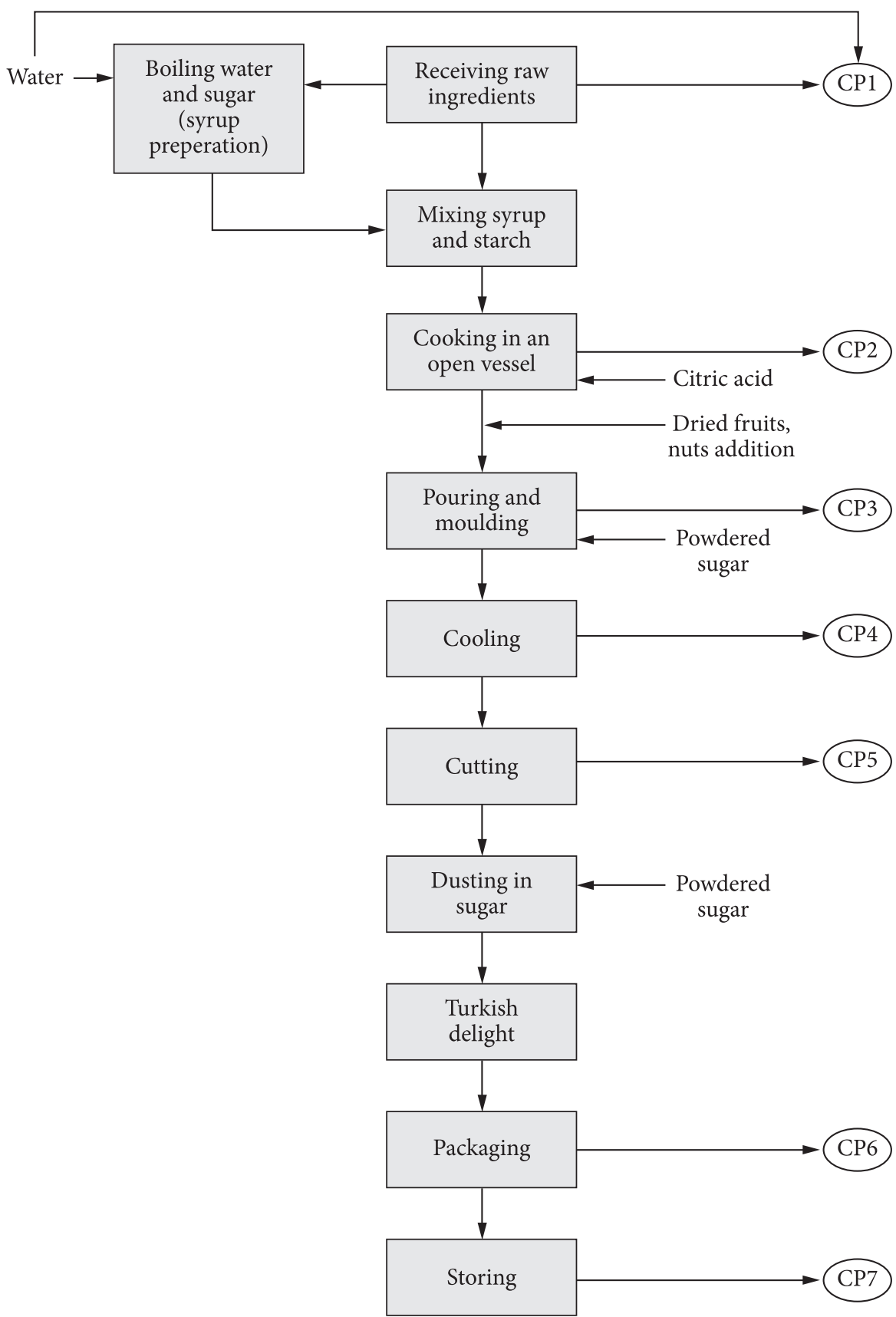

Figure 1. Flow diagram for Turkish delight production with critical points (CP). 
be inspected, and defective ingredients should be rejected immediately. The supplier must provide the documents certifying the safety of raw materials. Relative humidity, storage time, environmental temperature, moisture content of foods, sanitary conditions of the environment, and the number of insects in the environment need to be managed during production, processing, transportation, and storage of foods to avoid microbial growth and aflatoxin production
(ÖZYARAL et al., 2007; BIRCAN et al., 2008; GOK; BATU, 2008; CHULZE, 2010). Connecting to a public water system or installing water treatment devices to the production units can be the basic solutions for the potential risks in water since pesticides get into water primarily as runoff from the agricultural fields. Laboratory analyses should be carried out to ensure the safety of foods and water when necessary. Staff training, awareness of hazards, buying ingredients from reputable producers, proper

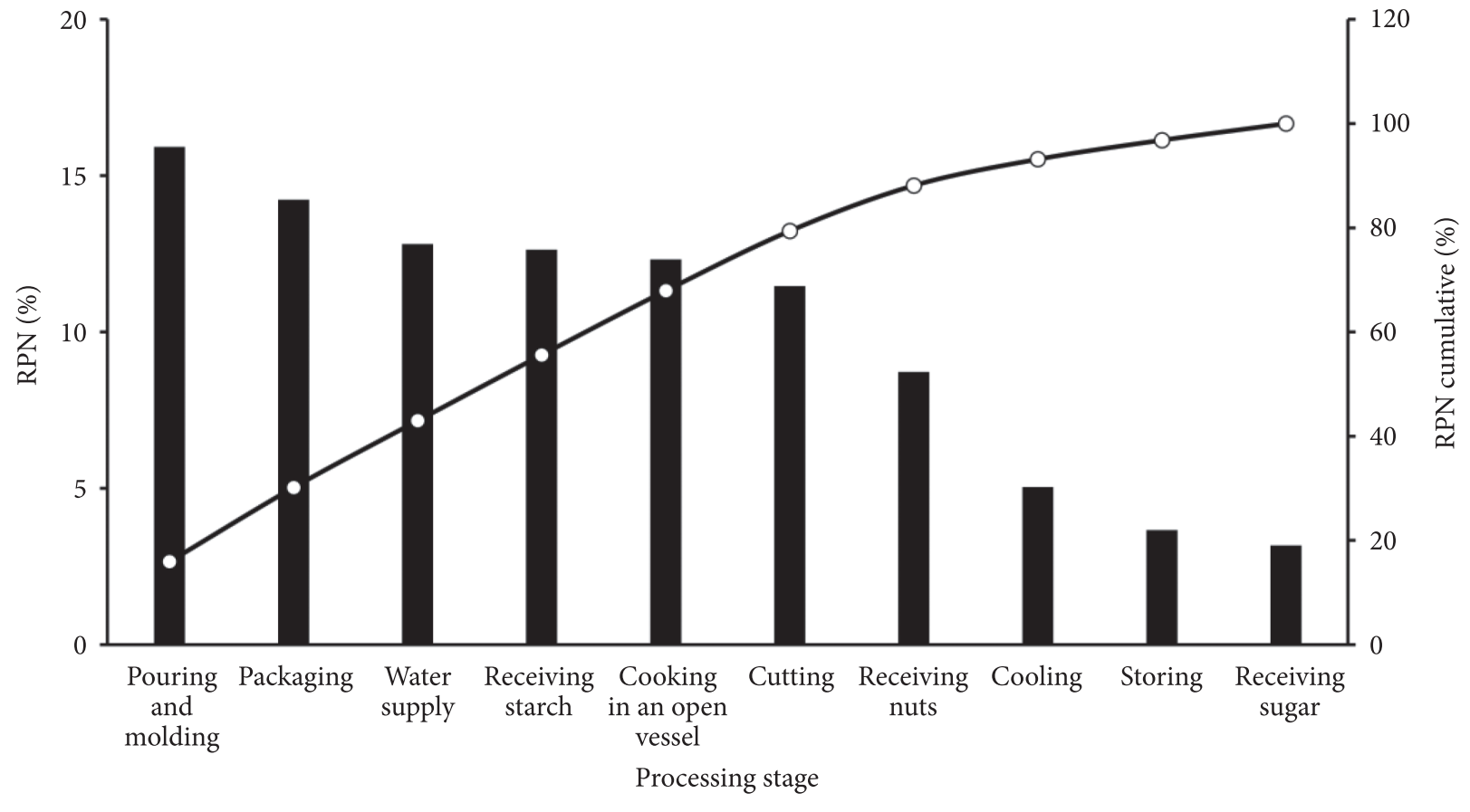

(b)



Processing stage

Figure 2. Pareto diagram for risk classification of Turkish delight production (a) prior to corrective actions, (b) after corrective actions. RPN: Risk Priority Number. 
Ozilgen

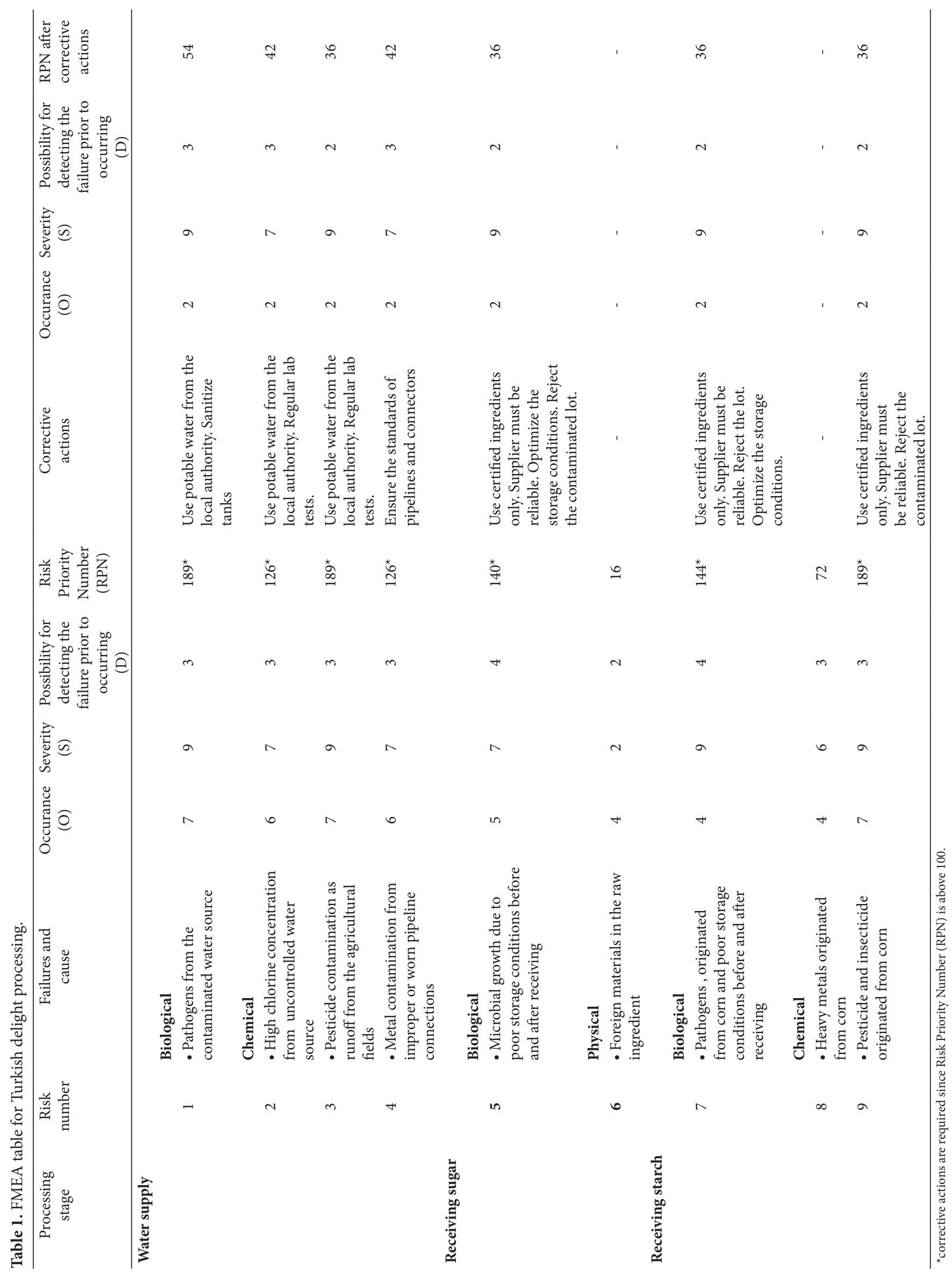


FMEA for confectionery manufacturing in developing countries

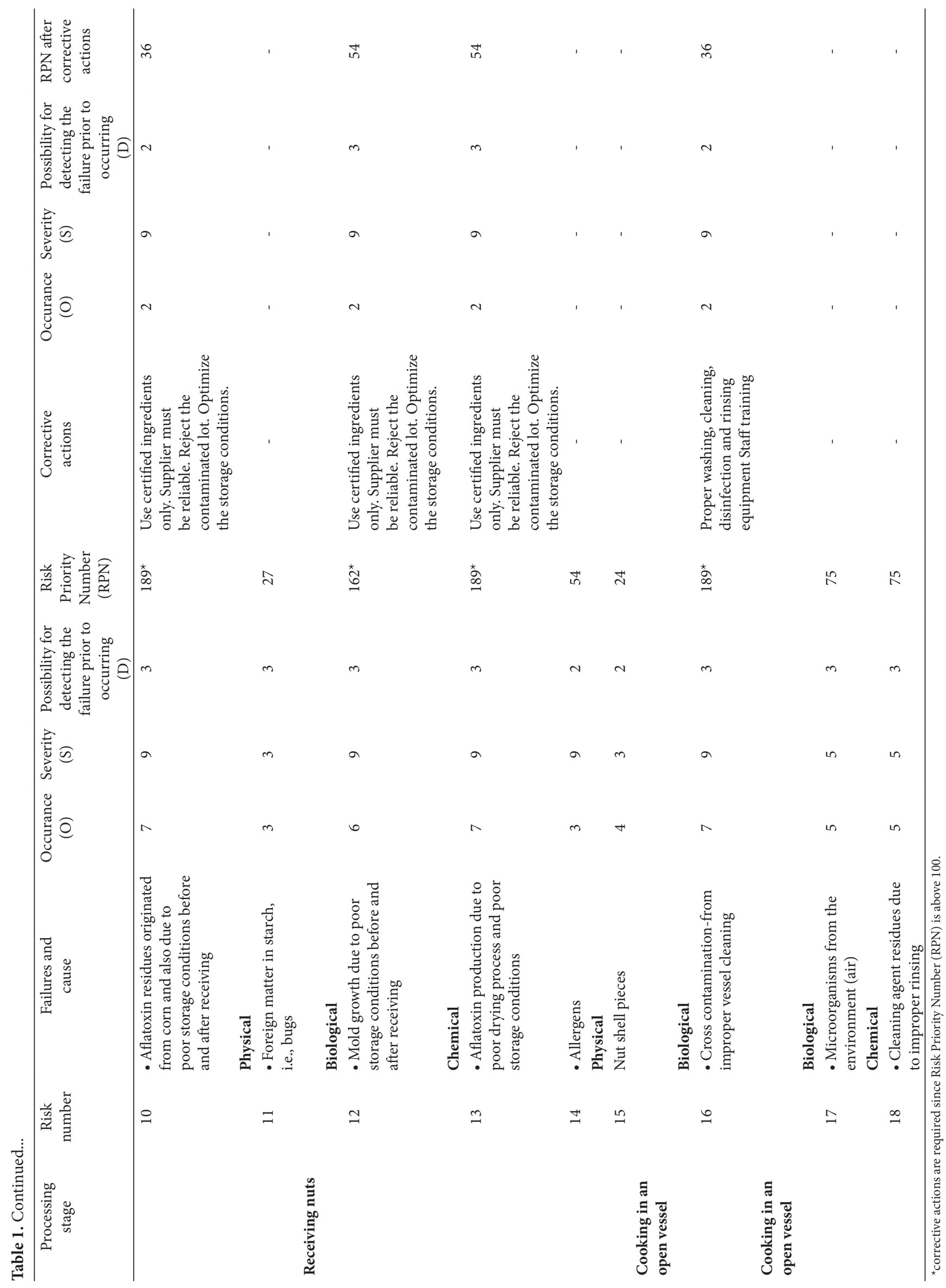




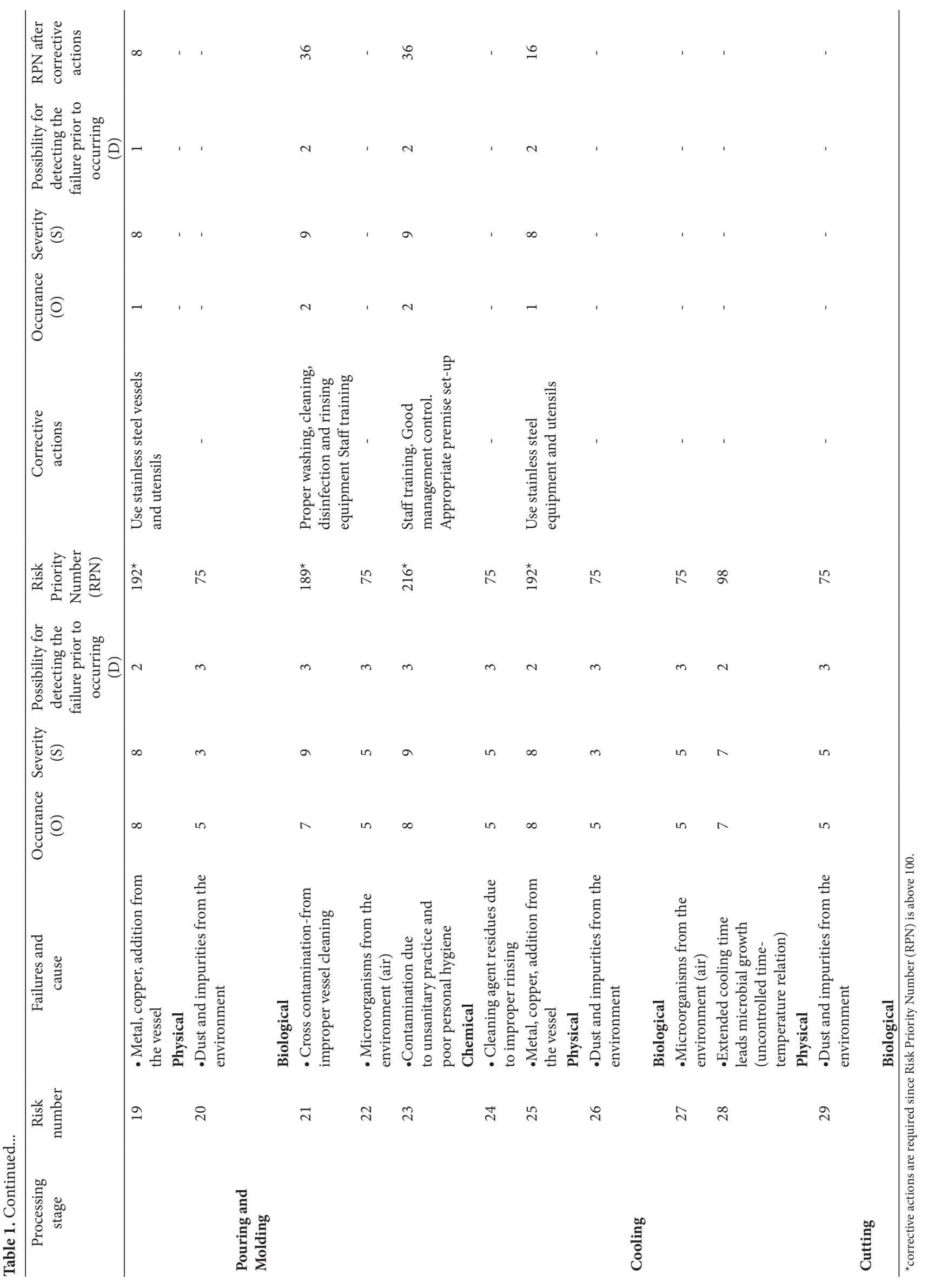


FMEA for confectionery manufacturing in developing countries

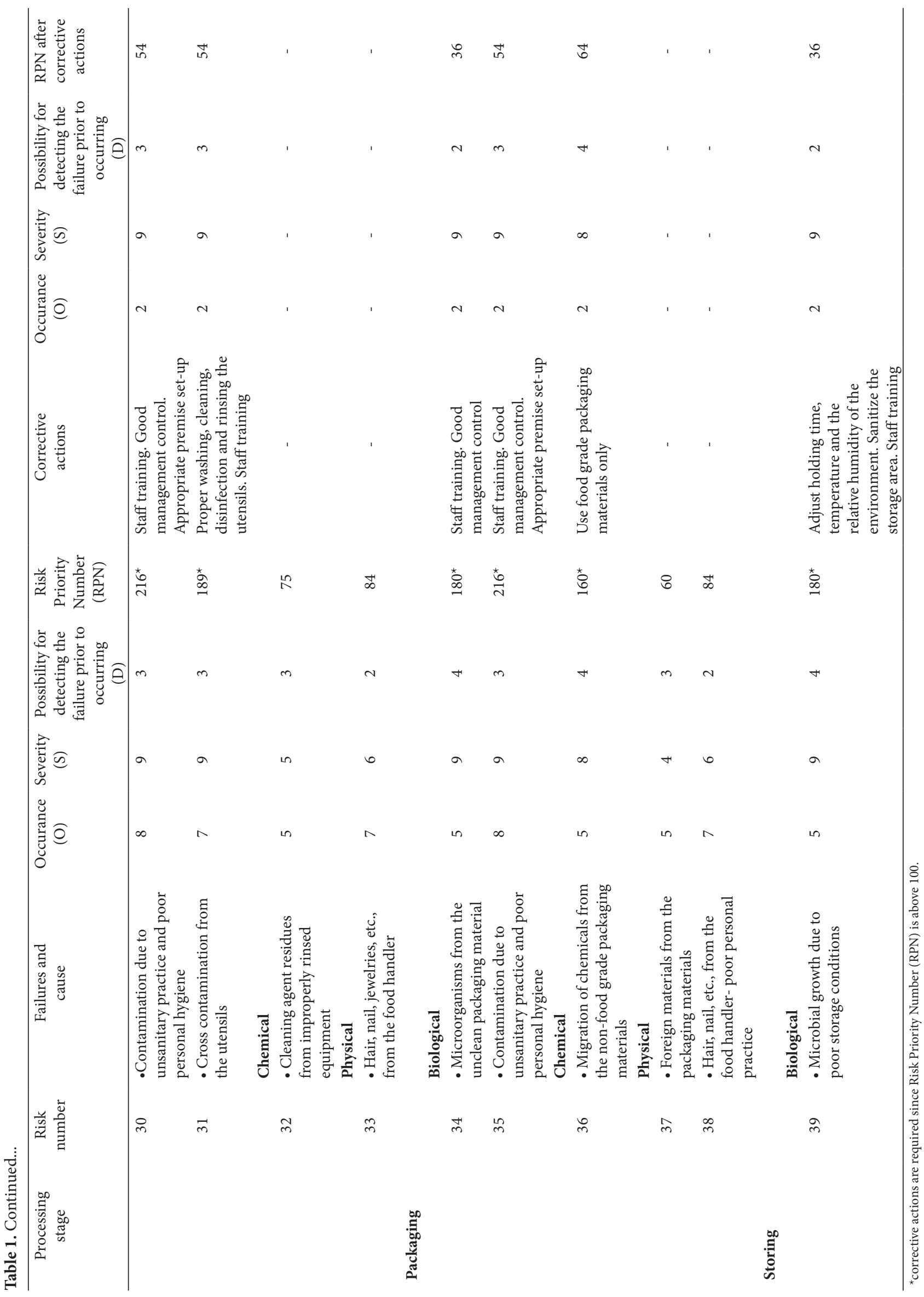


storage, and visual inspection might be acceptable for small companies since they do not have enough laboratory facilities and a strong purchasing power (WORLD..., 2008).

Turkish delight is usually manually placed in plastic bags or cardboard boxes in small-scale companies. The cardboard boxes are not free from microorganisms since the raw materials of paper contain bacteria, and box production is an open process. Ekman et al. (2009) reported microbial contamination of dry foods on the surface of paper boxes. Besides the microorganisms in the cardboard box, handling and storage conditions of the packaging materials prior to packaging are also important factors for the degree of cross-contamination in this stage (Table 1). Sometimes packaging itself becomes a source of chemical contamination through the migration of food packaging materials into foods. This should not exceed the acceptable limits defined in the food codex depending on the toxicological properties of the migrants (LAU; WONG, 2000). Food grade packaging materials must be used to avoid this problem (Table 1).

Genetically modified organisms (GMO) can be found in almost every corn-based food such as cornstarch, corn syrup, and corn oil. This possibility is not considered as a failure in Table 1 since health risks of GMOs are extensively assessed both at national and international level. However, the majority of people in Turkey believe that GM foods are harmful to health and are not to be used in the food industry. The consumers' opinion is very important for the market and the possibility of product rejection by consumers is quite strong in case of using GM foods. Detection of GMO is difficult and costly. Certificates or laboratory test results which prove the purity of corn starch, should be provided by the supplier, and product labeling should be done according to the regulations to protect the consumer right and to avoid frauds (RUTHER, 2009).

Suggested corrective actions for each failure mode were theoretically applied to the Turkish delight process, and RPNs were calculated for the new risk situation (Table 1). Pareto graphs visually show the high risk processing steps before taking the corrective actions and the new risk situation after the corrective actions (Figures 2a, b). The RPN values reduced below 100 after undertaking the suggested corrective actions. The results of this study highlight the importance of a systematic control to minimize or eliminate risks in confectionary production, which involves traditional methods and equipment in the process. The FMEA model can be of significant help in fulfilling this need. The results from this study might help large number of confectionary manufacturers in producing safe products since production of Turkish delight involves the use of the most common ingredients and processing stages in many other confectioneries.

\section{Conclusion}

This study applies the FMEA methodology to a small scale confectionery manufacturing company, in which traditional methods and equipment are involved in the processing stages. Poor personal hygiene and unsanitary practices were identified as the main reasons for the failures in the stages with the highest RPN. The use of traditional copper vessels and utensils, insufficient water pipeline connections, low quality raw ingredients, and poor storage conditions were also revealed as potential causes for the failures in the process. The suggested corrective actions considerably lowered the RPN values below the acceptable limit of 100 . The results of the present study clearly show the importance of incorporating a good systematic control system for risk management in the confectionary industry.

\section{References}

ARVANITOYANNIS, S. I .; SAVELIDES, S. C. Application of failure mode and effect analysis and cause and effect analysis and Pareto diagram in conjunction with HACCP to a chocolate-producing industry: a case study of tentative GMO detection at pilot plant scale. International Journal of Food Science \& Technology, v. 42, n. 11, p. 1265-1289, 2007. http://dx.doi.org/10.1111/j.13652621.2006.01304.x

ARVANITOYANNIS, S. I.; VARZAKAS, T. H. A conjoint study of quantitative and semi-quantitative assessment of failure in a strudel manufacturing plant by means of FMEA and HACCP, Cause and Effect and Pareto diagram. International Journal of Food Science and Technology, v. 42, p. 1156-1176, 2007a. http://dx.doi. org/10.1111/j.1365-2621.2006.01301.x

ARVANITOYANNIS, S. I.; VARZAKAS, T. H. Application of failure mode and effect analysis (FMEA), cause and effect analysis and Pareto diagram in conjunction with HACCP to a potato chips manufacturing plant. International Journal of Food Science \& Technology, v. 42, n. 12, p. 1424-1442, 2007b. http://dx.doi. org/10.1111/j.1365-2621.2006.01361.x

ARVANITOYANNIS, S. I.; VARZAKAS, T. H. Application of ISO 22000 and Failure Mode and Effect Analysis (FMEA) for industrial processing of salmon: a case study. Critical reviews in Food Science and Nutrition, v. 48, p. 411-429, 2008. PMid:18464031. http:// dx.doi.org/10.1080/10408390701424410

BATU, A.; KIRMACI, B. Production of Turkish delight. Food Research International, v. 42, p. 1-7, 2009. http://dx.doi.org/10.1016/j. foodres.2008.08.007

BIRCAN, C. et al. Aflatoxin levels in dried figs, nuts and paprika for export from Turkey. International Journal of Food Science and Technology, v. 43, p. 1492-1498, 2008. http://dx.doi.org/10.1111/ j.1365-2621.2008.01726.x

CHULZE, S. N. Strategies to reduce mycotoxin levels in maize during storage: a review. Food Additives and Contaminants, v. 27, p. 651-657, 2010. http://dx.doi.org/10.1080/19440040903573032

DILVIN, I. N.; ZORBA, N. Microbiological quality of Turkish Delights packed in different packaging Techniques. Electronic Journal of Food Technology, v. 1, p. 1-6, 2008. Disponível em: <http://www. teknolojikarastirmalar.com/pdf/en/02_030108_1_ipek_en.pdf>. Acesso em: 18 maio 2010.

DOYURAN, D. S.; GÜLTEKIN, M.; GÜVEN, S. Geleneksel Gidalardan Lokumun Üretimi Ve Özellikleri. Gıda Mühendisliği, v. 10, p. 63-67, 2006.

EKMAN, J. et al. Transfer of Bacillus cereus spores from the packaging paper into food. Journal of Food Protection, v. 72, p. 2236-2242, 2009. PMid:19903384.

GOK, V.; BATU, A. HACCP sisteminin lokum üretimine uygulanması. Gıda Teknolojileri Elektronik Dergisi, p. 19-25, 2008. <http:// www.teknolojikarastirmalar.com/pdf/tr/02_030108_4_gok_tr.pdf >. Acesso em: 28 abr. 2010. 
KLEEF, E. et al. Food risk management quality: Consumer evaluations of past and emerging food safety incidents. Health, Risk and Society, v. 112, p. 137-163, 2009. http://dx.doi. org/10.1080/13698570902784265

LAU, O.; WONG, S. Contamination in foods from packaging materialreview. Journal of Chromatography, v. 882, p. 255-270, 2000. http:// dx.doi.org/10.1016/S0021-9673(00)00356-3

MALHOTRA, R. et al. Profile of food handlers working in food service establishments located within the premises of a medical college in Delhi, India. Public Health, v. 121, p. 455-461, 2007. PMid:17280693. http://dx.doi.org/10.1016/j.puhe.2006.08.002

NEW JERSEY. Department of Health and Senior Services. Division Of Environmental And Occupational Health Consumer And Environmental Health Services. Facts pesticide. 2002. Disponível em: <http://www.state.nj.us/health>. Acesso em: 28 abr. 2010.

OZILGEN, S. Food safety education makes the difference: food safety perceptions, knowledge, attitudes, and practices among Turkish university students. Journal für Verbraucherschutz und Lebensmittelsicherheit, v. 6, p. 25-34, 2011. http://dx.doi. org/10.1007/s00003-010-0593-Z

OZILGEN, S.; BUCAK, S.; OZILGEN, M. Improvement of the safety of the red pepper spice with fmea and post processing ewma quality control charts. Chemistry of Food Science and Technology, 2011. http://dx.doi.org/10.1007/s13197-011-0371-7 http://dx.doi. org/10.1007/s13197-011-0371-7

ÖZYARAL, O. et al. Şeker ve şeker katkılı besin maddelerinde kserofilik-kserotoleran küfler Xerophilic and xerotolerant molds in candies and candied products. Turkish Microbiological Society, p. 43-50, 2007.

PALACIOĞLU, S. Şekerleme sektör profile. 2009. Disponível em: <http:www.ito.org.tr/Dokuman/Sektor/1-87.pdf>. Acesso em: 28 abr. 2010 .

RUTHER, B. Risk management of unintended GMO contamination in the supply chain of maize and processed maize products. In: EUROPEAN ASSOCIATION OF AGRICULTURAL ECONOMISTS - EAAE SEMINAR, 113., 2009, Chania, Greece.
Proceedings...Chania, Greece: European Association of Agricultural Economists, 2009.

SCIPIONI, A. et al. FMEA methodology design, implementation and integration with HACCP system in food company. Food Control, p. 495-501, 2002. http://dx.doi.org/10.1016/S0956-7135(02)00029-4

SEGISMUNDO, A.; MIGUEL, PAC. Failure mode and effects analysis (FMEA) in the context of risk management in new product development: A case study in an automotive company. International Journal of Quality and Reliability Management, v. 25, p. 899-912, 2008. http://dx.doi.org/10.1108/02656710810908061

SIRIKEN, B.; ÇADIRCI, O. Köfte (Pişmemiş), Yaş Pasta ve Lokumun Mikrobiyolojik Analizleri. In: ULUSAL VETERINER GIDA HIJYENI KONGRESI, 2., 2006, Istanbul. Proceedings... Istanbul: Ist. Üni. Veteriner Fak., 2006.

STERN, B. R. et al. Copper and Human Health: Biochemistry, Genetics, and Strategies for modeling dose-response relationships. Journal of Toxicology and Environmental health-Part B, p. 157-222, 2007.

SZOVATI, K.; BIACS, P.; KISS, A. Application of food quality methods in case bakery products. Hungarian Agricultural Research, p. 21-23, 2008.

TENG, S-H.; HO, S-Y. Failure mode and effects analysis: An integrated approach for product design and process control. International Journal of Quality \& Reliability Management, v. 13, p. 8-26, 1984 http://dx.doi.org/10.1108/02656719610118151

WORLD HEALTH ORGANIZATION - WHO. Chlorine in drinking-water background document for development of WHO guidelines for drinking-water quality. WHO, 2003. Disponível em: <http://www.who.int/water_sanitation_health/dwq/chlorine. pdf $>$. Acesso em: 28 abr. 2010.

WORLD HEALTH ORGANIZATION - WHO. Hazard analysis and critical control point generic models for some traditional foods: a manual for the Eastern Mediterranean region. WHO, 2008. Disponível em: <http://www.emro.who.int/ceha/pdf/E-HACCP. pdf.>. Acesso em: 18 abr. 2010.

YOUNES, M.; GALAL-GORCHEV, H. Pesticides in drinking water. Food and Chemical Toxicology, v. 38, p. 87-90, 2000. http://dx.doi. org/10.1016/S0278-6915(99)00132-5 